Aletheia

ISSN: $1853-3701$

publicaciones@fahce.unlp.edu.ar

Universidad Nacional de La Plata

Argentina

\title{
Introducción al dossier: Memorias desde las disidencias sexo-genéricas. Preguntas incómodas para desmontar el cisexismo heterosexual
}

Casi, Daniela; Rosas, Sabrina

Introducción al dossier: Memorias desde las disidencias sexo-genéricas. Preguntas incómodas para desmontar el cisexismo heterosexual

Aletheia, vol. 10, núm. 19, 2019

Universidad Nacional de La Plata, Argentina

DOI: https://doi.org/10.24215/18533701e024

Esta obra está bajo una Licencia Creative Commons Atribución-NoComercial-Compartirlgual 4.0 Internacional. 
Dossier: Memorias desde las disidencias sexo-genéricas. Preguntas incómodas para desmontar el cisexismo heterosexual.

\section{Introducción al dossier: Memorias desde las disidencias sexo-genéricas. Preguntas incómodas para desmontar el cisexismo heterosexual}

Daniela Casi

DOI: https://doi.org/10.24215/18533701e024

Facultad de Humanidades y Ciencias de la Educación,

Universidad Nacional de La Plata, Argentina

daniela.casi.unlp@gmail.com

Sabrina Rosas

Facultad de Humanidades y Ciencias de la Educación,

Universidad Nacional de La Plata, Argentina

rosas.sabrina7@gmail.com

El desafío de pensar y construir un dossier que reuniese algunas de las memorias de la disidencia sexual comenzó hace bastante tiempo. El dossier "Memorias desde las disidencias sexo-genéricas. Preguntas incómodas para desmontar el cisexismo heterosexual” es una propuesta que nos presentó grandes desafíos y nos generó nuevos interrogantes sobre cómo habitamos los espacios académico-universitarios, cómo hacemos y construimos las memorias, qué preguntas acompañan nuestras prácticas de investigación y docencia, e incluso qué vínculos causales existen entre nuestros campos de estudios y nuestras propias historias personales, movidas desde la propia disidencia.

En verdad, este dossier temático se presentó en sus inicios como una apuesta a construir un espacio de diálogo sobre las memorias trans y travesti en nuestro país. Pero no buscábamos hablar de y por las memorias trans y travesti, sino que nos interesaba convocar a compañeres que quisieran y pudieran escribir y recuperar sus propios pasados y presentes, hablando en primera persona. Las dificultades nos desbordaron. No en función de sus posibilidades ontológicas, e incluso más allá de las problemáticas epistémicas y metodológicas que implica la ardua discusión sobre la legitimidad de un testimonio, sobre la posibilidad de hablar del subalterno de la que Spivak ya ha teorizado. Comenzamos a pensar a qué personas convocar para escribir, que formaran parte del mundo académico, o bien que pudieran narrar desde su experiencia, reflexiones en torno a los modos de construcción de las memorias sociales.

La imposibilidad de concretar esta apuesta vislumbra una multiplicidad de problemáticas. Nos encontramos con posicionamientos teórico-políticos de quienes decidieron circular sus experiencias por circuitos de información y comunicación alternativos al académico; de muches compañeres que expresaron no sentirse cómodes escribiendo "para la academia", o con un "determinado formato de escritura”. También nos encontramos con quienes decidieron disputar este espacio y algunas de sus formas de construcción del saber. En este contexto, re-encaminamos la propuesta inicial y buscamos avizorar experiencias y memorias de identidades sexo-genéricas en un sentido más amplio.

Diversas charlas con referentes en la temática nos permitieron comenzar a esbozar algunos apuntes frente a los interrogantes que nos abrían estas áreas de vacancia. No como respuestas acabadas sino como disparadores reflexivos. Resultó fundamental la que entablamos junto a Blas Radi, docente investigador de la UBA y co-coordinador de la Cátedra Libre de Estudios Trans. Charlas que derivaron, posteriormente, en un texto dialógico que conforma este dossier, titulado "Políticas trans y acciones afirmativas en los ámbitos universitarios. Conversaciones necesarias para deshacer el cisexismo". En el mismo nos preguntamos cuáles son las dificultades que encuentran las personas trans en el ámbito universitario y cómo analizar las 
ausencias latentes en ámbitos académicos. La primera dificultad de las políticas de inclusión es la pretensión de poder delimitar a "lo trans" como grupo identificable y definible, cuando precisamente las personas viven y experimentan sus identidades a partir de múltiples formas, no necesariamente expuestas, visibles o exteriorizables para los otros. Otros cuyas miradas, delineadas por el cisexismo y la heteronormatividad, nos exigen más o menos deliberadamente coherencia dentro del orden binario. Como explica Blas, la reproducción del sentido común del género que entiende que hay dos sexos en tanto hay dos géneros, impulsa acciones de "inclusión" que pretenden ponerle un freno al sexismo pero son insuficientes para desmontar el cisexismo. Entonces, Blas nos interpela: “¡cómo pretender que las personas trans sean reconocidas como agentes epistémicos si son desconocidos deliberadamente?" La discusión es política, y se gesta en qué decimos cuando hablamos de género. $Y$ es que antes que interrogarnos sobre la presencia más o menos explícita de personas trans en la universidad, debemos deconstruir qué decimos cuando nombramos al "colectivo trans" del modo en el que lo enunciamos, y desmontar la idea de que lo primero que podemos decir sobre elles, es su historia de exclusión.

¿Cómo hacemos memorias de las disidencias sexuales y de género? ¿Cómo pueden recuperarse las memorias trans, las memorias maricas, las memorias tortas, las memorias queers, cuando éstas se han gestado en el violento silencio disciplinador, cis hetero patriarcal, racista, capacitista, clasista y odiante? Algunas de estas preguntas recorren la reflexión autobiográfica de Facu Saxe en su texto Hacia un cuerpo marica: una reflexión situada sobre investigación, memoria queer/cuir, infancia sexo-disidente y trols, docente e investigadora de la casa violentamente perseguida y hostigada en el mundo mediático. Puntualmente se ocupa de pensar las formas en las que es posible construir memorias desde y de la disidencia sexual, un recuerdo pensado desde la subversión sexo-género. Sin pretensiones universalizantes, y desde la reflexión de nuestras "autohistoriasteorías", Facu nos convida a hacer hablar a ese silencio que constituye nuestro ser marica, nuestro ser torta, nuestro ser trans, para contaminar la normalidad cisheteropatriarcal, históricamente represora y silenciadora.

Frente a la imperiosa necesidad de construir lo que no ha tenido enunciación, de recuperar los silencios, las tareas son muchas y de muches. El texto del Archivo Potencia Tortillera titulado Potencia Tortillera: memorias del activismo lésbico en primera persona. Aprendizajes y desafios del archivo digitalizado del activismo lésbico en Argentina, precisamente, es un aporte en tal sentido, al "romper el silenciamiento de la heterosexualidad obligatoria”. En su propuesta de recuperación de la memoria y de apropiarnos de nuestra historia colectiva como lesbianas y activistas, el Archivo ofrece una de las pocos plataformas virtuales existentes en la actualidad. Con más de mil posteos que recorren experiencias lésbicas desde 1970 hasta la fecha, el Archivo nuclea historias, textos e imágenes. La imagen de tapa seleccionada para este número de Aletheia refleja precisamente uno de estos instantes atesorados en el tiempo, la Segunda Marcha del Orgullo Lésbico-Gay, de 1993. Como apuesta política y militante, las compañeras del archivo nos invitan a pensar a la memoria como posibilidad de imaginar un futuro, un acto devastador y creativo.

En este desafío, creemos necesario construir nuestras memorias. Hablar por nosotres mismes, o como propone Cristian Prieto, en su texto Las memorias de la disidencia sexual: subjetivas, individualizadas y fuera de los estándares tradicionales del "hacer memoria": la memoria se hace con otres. El autor de "Fichados. Crónicas de amores clandestinos", nos acerca un texto, en el que plantea que es sumamente escasa la posibilidad de llegar a los relatos disidentes del pasado, si se lo pedimos como respuesta a las instituciones heteronormadas, constructoras y reproductoras de las lógicas binarias del cisexismo. A la vez, desde un formato poético, mientras expresa su convicción política de que la memoria "no es un privilegio heterosexual", señala que tampoco lo es de clase social. Entonces visibiliza la situación de las memorias de las disidencias sexuales de los sectores populares, doblemente silenciadas.

En el último aporte a este dossier, nos encontramos con la conversación de Quimey Sol Ramos y Andrea Raina: una entrevista titulada "Aprendiendo en el 'más acá". En este diálogo, Quimey, educadora del Bachillerato Trans Mocha Celis, nos comparte una serie de reflexiones, que parten de la pregunta “¿Qué 
significa "memoria, verdad y justicia para vos?"; entonces ella nombra "la verdad travesti”, una verdad que se grita con furia; y retoma a su compañera Marlene Wayar para señalar el genocidio a las identidades trans y travestis. Quimey nos convoca a construir otras memorias, otros relatos, otras representaciones, que puedan "desandar los mitos", que cuestionen la reproducción de "lo posible y lo imposible" e impulsen mundos otros desde el teje de "trincheras afectivas, políticas, deseantes y colectivas".

\section{BY-NC-SA}

